\title{
PENERAPAN MODEL PEMBELAJARAN KONTEKSTUAL UNTUK MENINGKATKAN HASIL BELAJAR IPS SISWA KELAS IV SEKOLAH DASAR
}

\begin{abstract}
Nana Setiana ${ }^{1}$
ABSTRAK

Proses pembelajaran IPS di sekolah dasar ternyata masih berlangsung kurang efektif.Hal ini ditandai dengan munculnya beberapa masalah, antara lain (1) minimnya motivasi belajar siswa dalam pembelajaran, (2) indikasi penggunaan model penugasan/ resitasi sehingga siswa tidak mendapat bimbingan dalam proses pembelajaran, dan (3) tidak ada interaksi aktif antara komponen belajar. Sejalan dengan kondisi tersebut diperlukan penerapan model pembelajaran yang tepat yang salah satunya adalah model pembelajaran kontekstual. Oleh sebab itu, tujuan penelitian ini adalah untuk mendeskripsikan dan meningkatkan (1) proses pembelajaran dengan menerapkan model pembelajaran kontekstual dalam pembelajaran IPS tentang perkembangan teknologi transportasi pada siswa kelas IV sekolah dasar; dan (2) hasil belajar siswa kelas IV sekolah dasar pada konsep perkembangan teknologi transportasi dengan menggunakan model pembelajaran kontekstual.Metode penelitian yang digunakan dalam penelitian ini adalah metode Penelitian Tindakan Kelas penelitian (PTK). Penelitian ini dilakukan di sebuah sekolah dasar di Kabupaten Bandung dengan subjek penelitian sejumlah 16 orang siswa yang terdiri dari 9 siswi perempuan dan 7 siswa laki-laki. Untuk memperoleh data yang benar, digunakan instrumen penelitian berupa catatan lapangan, pedoman wawancara, pengetesan, dokumentasi dan kuesioner. Teknik analisis data yang digunakan, yaitu analisis data kualitatif dan kuantitatif. Hasil penelitian menunjukkan bahwa (1) model pembelajaran kontekstual dapat diterapkan dalam pembelajaran IPS tentang perkembangan teknologi transportasi karena langkah-langkah model ini mampu dilaksanakan guru dengan efektif sehingga proses pembelajaran menjadi lebih kondusif dan siswa semakin aktif dan kreatif; dan (2) model pembelajaran kontekstual dapat digunakan untuk meningkatkan kemampuan siswa dalam memahami materi perkembangan teknologi transportasi. Hal ini ditunjukkan dengan meningkatnya pemahaman siswa dalam materi tersebut.
\end{abstract}

Kata Kunci: Hasil Belajar,Model Pembelajaran Kontekstual, Pembelajaran IPS, Siswa SD

\section{A. PENDAHULUAN}

Pendidikan di sekolah dasar yang diselenggarakan selama 6 tahun bertujuan untuk memberikan kemampuan dasar bagi para siswa sebelum mengikuti pendidikan lanjutan. Untuk mencapai tujuan tersebut, pemerintah telah menetapkan kurikulum yang berisi sejumlah mata pelajaran beserta susunan bahan kajian pada mata pelajaran tersebut. Berhubungan dengan hal ini, pelajaran IPS merupakan salah satu mata pelajaran yang terdapat dalam kurikulum tersebut.

${ }^{1}$ Dosen PGSD UPBJJ UT Bandung 
Rambu-rambu pelaksanaan pembelajaran IPS SD menyebutkan bahwa pengajaran IPS hendaknya dilaksanakan dengan kekhasan konsep/materi pokok dan perkembangan berpikir siswa SD. Ini berarti bahwa konsep-konsep dasar IPS hendaknya dipahami siswa dengan baik agar siswa beroleh pengetahuan yang memadai tentang konsep IPS.

Salah satu faktor yang dapat meningkatkan pemahaman siswa dalam pembelajaran adalah guru. Guru yang berkualitas dan profesional merupakan kunci keberhasilan pendidikan melalui proses belajar mengajar sebagaimana digariskan dalam setiap perubahan kurikulum. Unsur guru adalah unsur strategis dalam dunia pendidikan khususnya pendidikan dasar.Mengacu kepada penyataan di atas, salah satu hal yang harus diperhatikan guru dalam pembelajaran adalah kemampuannya dalam memilih dan menggunakan model, metode, dan media/alat peraga serta sumber belajar yang sesuai dengan materi pelajaran yang disampaikannya.Tetapi pada kenyataannya sampai saat ini guru belum mampu menentukan model, metode, dan media/alat peraga serta sumber belajar yang tepat untuk digunakan dalam pembelajaran sehingga berdampak negatif terhadap perolehan hasil belajar siswa.

Kekurangmampuan guru dalam menentukan model, metode, dan media/alat peraga serta sumber belajar yang tepat juga terjadi pada saatguru melaksanakan pembelajaran IPS. Hal ini berdampak terhadap rendahnya kemampuan siswa dalam memahami materi pembelajaran IPS termasuk pada materi perkembangan teknologi transportasi. Salah satu contoh konkret adalah rendahnya kompetensi siswa dalam membedakan jenis-jenis alat transportasi tradisional dan modern. Hal ini dapat dilihat dari nilai rata-rata siswa kelas IV SD di sekolah yang dijadikan lokasi penelitian untuk mata pelajaran IPS hanya 60 masih dibawah kriteria ketuntasan minimal (KKM) yaitu 75.

Rendahnya nilai tersebut antara lain dipengaruhi oleh pemilihan model pembelajaran pembelajaran yang tidak tepat. Biasanya guru hanya menggunakan metode ceramah, tanya jawab dan penugasan. Metode-metode tersebut merupakan model pembelajaran tradisional dan dipandang tidak efektif untuk membantu siswa mengembangkan pengetahuannya, keterampilannya, maupun tingkah lakunya. Jelasnya, model pembelajaran tradisional tidak banyak membantu mengembangkan segenap potensi siswa secara optimal. Dalam model pembelajaran ini, dominasi guru dalam proses pembelajaran begitu kuat, sehingga guru seolah-olah berperan sebagai satu-satunya "informations giver" disamping buku teks, dan siswa berada pada posisi sebagai "passive learnes" yang harus mengikuti instruksi-instruksi guru. Dampaknya, kemampuan siswa akan terhambat oleh dominasi guru.

Salah satu model pembelajaranyang tepat digunakan dalam pembelajaran IPS tentang perkembangan teknologi transportasi adalah model pembelajaran kontekstual. Dalam pembelajaran kontekstual, program pembelajaran lebih merupakan rencana kegiatan kelas yang dirancang guru, yang berisi skenario tahap demi tahap tentang apa yang akan dilakukan bersama siswanya sehubungan dengan topik yang akan dipelajarinya. Dalam program tercermin tujuan pembelajaran, media untuk mencapai tujuan tersebut, materi pembelajaran, langkah-langkah pembelajaran, dan authentic assessmen-nya. Dalam konteks itu, 
program yang dirancang guru merupakan rencana pribadi tentang beberapa hal yang akan dikerjakan bersama siswanya. Dengan model pembelajarankontekstual, siswa akan langsung dihadapkan pada objek nyata.Sejalan dengan uraian di atas, dalam penelitian ini penulis akan menggunakan model pembelajarankontekstual dalam meningkatkan kemampuan siswa pada pembelajaran IPS tentang konsep perkembangan teknologi transportasi.

Berdasarkan latar belakang masalah di atas, masalah dalam penelitian ini dapat dirumuskan sebagai berikut :

1. Bagaimana penerapan model pembelajaran kontekstual dalam pembelajaran IPS tentang perkembangan teknologi transportasi pada siswa kelas IV Sekolah Dasar?

2. Bagaimana hasil belajar siswa kelas IV Sekolah Dasar pada konsep perkembangan teknologi transportasi dengan menggunakan model pembelajarankontekstual ?

Tujuan penelitian ini adalah untuk mendeskripsikan dan meningkatkan dua hal sebagai berikut.

1. Proses pembelajaran dengan menerapkan model pembelajarankontekstual dalam pembelajaran IPS tentang perkembangan teknologi transportasi pada siswa kelas IV sekolah dasar.

2. Hasil belajar siswa kelas IV sekolah dasarpada konsep perkembangan teknologi transportasi dengan menggunakan model pembelajarankontekstual.

\section{B. KAJIAN PUSTAKA}

\section{Pembelajaran IPS}

Konsep dasar tentang pendidikan IPS perlu dirumuskan secara jelas agar dapat memberikan gambaran serta arahan bagi pengembangan penelitian. Dikemukakan Strong (Sutisyana, 1997: 9) bahwa dasar filosofis sangat penting dalam mengembangkan pemikiran konseptual dalam pendidikan ilmu pengetahuan sosial. Rumusan konseptual yang paling tepat khususnya di Indonesia adalah dengan dikembangkan berdasarkan realita, kondisi sosial budaya sebagai landasan pengembangan pendidikan ilmu sosial, serta tidak perlu dirumuskan dalam bentuk yang menekankan pada keseragaman.Dasar filosofis di atas adalah mencerminkan bahwa dalam pembelajaran IPS seyogyanya siswa ditempatkan sebagai subjek didik, sehingga ia mampu menumbuhkembangkan berbagai potensi yang dimilikinya.

Untuk mengkaji konsep dasar IPS yang harus dijadikan dasar filosofis pada setiap jenjang pendidikan dan pembelajarannya, perlu dikaji secara kronologis melalui beberapa definisi dan penjelasan tentang arti IPS (Social Studies) di antaranya Bank (1990: 3) menyatakan bahwa bahwa pendidikan IPS (social studies) merupakan bagian dari kurikulum di sekolah yang bertujuan untuk membantu mendewasakan siswa supaya dapat mengembangkan pengetahuan, keterampilan, sikap, dan nilai-nilai dalam rangka berpartisipasi di dalam masyarakat, negara dan dunia. Soemantri (2000:3) mengemukakan batasan pendidikan IPS digambarkan sebagai "program pendidikan yang memilih bahan pendidikan dari disiplin ilmu-ilmu sosial dan humanities yang diorganisasikan dan disajikan secara ilmiah dan psikologis untuk tujuan pendidikan”. 
Batasan Pendidikan IPS tersebut diadaptasi dari batasan Edgar Wesley, Frasser and West dan National Council for the Social Studies (NCSS), yaitu organisasi profesional yang secara khusus membina dan mengembangkan semacam pendidikan IPS pada tingkat pendidikan dasar dan menengah, serta keterkaitannya dengan disiplin ilmu-ilmu sosial dan disiplin ilmu-ilmu pendidikan. Untuk memberikan gambaran secara utuh tentang konsep pendidikan IPS (social studies) menurut NCSS (1994:3) mengungkapkan secara jelas bahwa pendidikan IPS adalah merupakan kajian terpadu "tematik", yang terdiri dari ilmu-ilmu social dan ilmu-ilmu kemanusiaan untuk meningkatkan kemampuan kewarganegaraan (civic competence). Di dalam program persekolahan, IPS menyediakan kajian terkoordinasi dan sistematis dengan mengambil intisari materi dari berbagai disiplin ilmu seperti antropologi, arkeologi, ekonomi, geografi, sejarah, hukum, ilmu politik, psikologi, agama, dan sosiologi, juga isi yang sesuai dengan ilmu-ilmu kemanusiaan, yaitu matematika dan ilmu alam.

Dilandasi oleh definisi-definisi yang telah di kemukakan di atas, maka memberikan kejelasan bagi kita bahwa pendidikan IPS bukan mata pelajaran disiplin ilmu tunggal, melainkan gabungan dari berbagai disiplin ilmu atau dapat disebut ilmu terpadu (interdisipliner). Dengan demikian secara umum, konsep pendidikan IPS (social studies) dapat diartikan sebagai studi mengenai interelasi ilmu-ilmu sosial dalam menelaah gejala dan masalah sosial yang terjadi di masyarakat. Atau diartikan sebagai usaha mengadakan interelasi ilmu-ilmu sosial dalam mengkaji gejala dan masalah sosial yang terjadi di masyarakat (Sumaatmadja, 2001: 38). Pada batasan tersebut terdapat beberapa konsep yang perlu mendapat kejelasan lebih lanjut terutama berkenaan dengan interelasi ilmuilmu sosial, gejala sosial, dan masalah sosial. Dalam mengungkap gejala dan masalah sosial tidak dapat diungkap hanya dengan menggunakan satu atau dua bidang ilmu pengetahuan sosial saja, karena gejala dan masalah sosial merupakan ungkapan hasil hubungan beberapa aspek kehidupan sosial. Artinya dalam kerangka kerja studi sosial, siswa dituntut untuk menghubungkan beberapa bidang ilmu pengetahuan sosial sesuai dengan gejala dan masalah sosial yang sedang ditelaah.

Untuk menelusuri lebih mendalam tentang istilah IPS yang digunakan pada persekolahan di Indonesia, secara kronologis dapat di paparkan bahwa istilah IPS merupakan salah satu label mata pelajaran di Sekolah Dasar dan menengah. Pemikiran tentang IPS di Indonesia, pada hakikatnya diilhami oleh kurikulum di Negara-negara Barat yang sudah berkembang lebih dulu, terutama Amerika Serikat sebagai salah satu negara yang telah menunjukkan reputasi akademis dalam bidang IPS. Reputasi tersebut tampak pada perkembangan pemikiran berbagai karya akademis yang dipublikasikan oleh National Council for the Social Studies (NCSS) yang pertama kalinya sejak tanggal 20-30 November 1935 hingga sekarang. Dalam pertemuan itu disepakati bahwa "Social Sciences the core of the curriculum" dalam kerangka pemikiran yang belum solid, karena pertemuan tersebut penuh dengan kebingungan dan dengan refleksi pemikiran yang tidak jelas sebagai dampak dari perdebatan kaum intelektual yang tidak terselesaikan di tengah-tengah situasi sosial, politik, dan ekonomi yang penuh gejolak. Longstreat, 1965 (Winataputra, 2007:1.3). 
Sebagai pilar historis-epistemologis social studies yang pertama berupa definisi tentang social studies telah dipancangkan oleh Edgar Bruce Wesley pada tahun 1937 (Barr, et.al. 1978), yaitu "The social studies as the social science simplified pedagogical purpose”. Maksudnya adalah bahwa sosial studi adalah ilmu-ilmu sosial yang disederhanakan untuk tujuan pendidikan, (Winataputra, 2007: 1.3).

Pendidikan Ilmu Pengetahuan Sosial yang di dalamnya mencakup ilmu sejarah, ilmu ekonomi, ilmu politik, sosiologi, antropologi, psikologi, geografi, dan filsafat yang disederhanakan dan dipilih untuk tujuan pembelajaran pada jenjang sekolah dan perguruan tinggi. Untuk kebermaknaan pemahaman konsep pada setiap jenjang pendidikan itu, maka aspek dari masing-masing disiplin ilmu sosial perlu diseleksi sesuai dengan tujuan pembelajaran tersebut,sehingga social studies dapat berperan sebagai ajang latihan sikap "reflektif thinking” (Barr, dkk. 1978: 37) dan diperkuat oleh Shirley Engle menerbitkan buku "Decission making”.

Selanjutnya berkaitan dengan definisi social studies (Barr, dkk.1978: 1719), mengmukakan bahwa "Social studies is an integration of social sciences and humanisties for the purposes of instruction in the citizenship. We empasize integration for social studies is the only field wich deliberately stempt...”. Definisi tersebut mengandung tiga tradisi, yaitu tradisi pedagogis, yang di dalamnya tersirat tentang: 1) social studies merupakan suatu sistem pengetahuan terpadu, 2) misi utama social studies adalah pendidikan kewarganegaraan, 3) sumber utama konten social studies adalah social sciences dan humanisties, 4) dalam upaya menyiapkan masyarakat yang demokratis, terbuka kemungkinan perbedaan dalam orientasi, visi, tujuan, dan metode pembelajaran.

Pengembangan dari ketiga tradisi sosial tersebut, masing-masing dapat di uraikan sebagai berikut:

1) Tradisi Citizenship Transmmision

Merupakan suatu modus pembelajaran sosial yang bertujuan utuk mengembangkan warga Negara yang baik, yang ditandai oleh "comforms certain accepted practice, hold particular beliefs, is loyal to certain values, participates in certain activities, and conforms to norms which are oftrn local character (Barr,dkk, 1978: 22). Dapat diartikan bahwa tradisi ini bertujuan untuk mengembangkan warga negara yang baik sesuai dengan norma yang telah diterima secara baku dalam negaranya;

2) Tradisi Social Science

Merupakan modus pembelajaran sosial yang betujuan mengembangkan karakter warga negara yang baik. Artinya tradisi ini memusatkan perhatian pada upaya untuk mengembangkan karakter warga negara yang baik yang ditandai oleh kemampuan dalam melihat dan mengatasi masalah-masalah sosial dan personal dengan menggunakan visi dan cara kerja sosial;

3) Tradisi Reflektif Inquiry:

Merupakan modus pembelajaran sosial yang menekankan pada hal yang sama, yaitu pengembangan warga negara yang baik dengan kriteria yang berbeda, yaitu memusatkan perhatian pada pengembangan karakter warga 
Negara yang baik dengan ciri pokok mampu mengambil keputusan. (Barr, dkk.1978: 17-19)

\section{Model Pembelajaran Kontekstual}

Model Pembelajaran kontekstual (Contextual Teaching and Learning (CTL)) merupakan konsep belajar yang membantu guru mengaitkan antara materi yang diajarkannya dengan situasi dunia nyata siswa dan mendorong siswa membuat hubungan antara pengetahuan yang dimilikinya dengan penerapannya dalam kehidupan mereka sebagai anggota keluarga, masyarakat, dan dunia kerja nantinya. Dengan konsep itu, hasil pembelajaran dihadapkan lebih bermakna bagi siswa. Proses pembelajaran berlangsung alamiah dalam bentuk kegiatan siswa bekerja dan mengalami, bukan transfer pengetahuan dari guru ke siswa. Dalam hal ini, strategi pembelajaran lebih dipentingkan daripada hasil.

Dalam pembelajaran kontekstual, siswa perlu mengerti apa makna belajar, apa manfaatnya, dalam status apa mereka, dan bagaimana mencapainya. Mereka sadar bahwa yang mereka pelajari berguna bagi hidupnya nanti. Mereka mempelajari apa yang bermanfaatbagi dirinya dan berupaya menggapainya. Dalam upaya itu, mereka memerlukan guru sebagai pengarah dan pembimbing. Oleh sebab itu, pembelajaran kontekstual pada dasarnya adalah usaha memperkenalkan siswa terhadap konteks secara luas yang meliputi situasi-situasi yang berhubungan dengan kehidupannya, fenomena nyata, isu-isu sosial, aplikasi teknologi yang kesemuanya dipahami benar oleh siswa baik pada masa kini maupun pada masa yang akan datang (Nurhadi, $2003: 1$ )

Model pembelajaran kontekstual merupakan suatu proses pendidikan yang holistik dan bertujuan memotivasi siswa untuk memahami makna materi pelajaran yang dipelajarinya dengan mengaitkan materi tersebut dengan konteks kehidupan mereka sehari-hari (konteks pribadi, sosial, dan kultural) sehingga siswa memiliki pengetahuan/ keterampilan yang secara fleksibel dapat diterapkan (ditransfer) dari satu permasalahan /konteks ke permasalahan/konteks lainnya (Ibrahim, 2007 : 3).

Sedangkan menurut Nurhadi (2003 : 1) bahwa pendekatan kontekstual (Contextual Teaching and Learning/CTL) adalah konsep belajar yang membantu guru mengaitkan antara materi yang diajarkannya dengan situasi dunia nyata dan mendorong pembelajar membuat hubungan antara materi yang diajarkannya dengan penerapannya dalam kehidupan mereka sebagai anggota keluarga dan masyarakat.

Dalam kelas kontekstual, tugas guru adalah membantu siswa mencapai tujuannya. Maksudnya, guru lebih banyak berurusan dengan strategi daripada memberi informasi. Tugas guru mengelola kelas sebagai sebuah tim yang bekerja bersama untuk menemukan sesuatu yang baru bagi anggota kelas (siswa). Sesuatu yang baru datang dari menemukan sendiri bukan dari apa kata guru. Begitulah peran guru di kelas yang dikelola dengan model pembelajaran kontekstual.

Kontekstual hanya sebuah strategi pembelajaran. Seperti halnya strategi pembelajaran yang lain, kontekstual dikembangkan dengan tujuan agar pembelajaran berjalan lebih produktif dan bermakna. Dalam pelaksanaannya pembelajaran kontekstual memiliki beberapa strategi atau bentuk pembelajaran 
untuk membangun konteks dalam pikiran siswa. Strategi-strategi tersebut antara lain:

1. relating (menghubungkan) dalam hal ini belajar dilakukan dengan menghubungkan pengalaman hidup dengan hal baru yang akan dipelajari;

2. experiencing (mengalami) dalam hal ini belajar dilakukan dengan cara mengenalkan siswa langsung pada sebuah masalah/contoh sehingga siswa dapat menemukan dan merumuskan pengetahuan secara mandiri.

3. applying (menerapkan) dalam hal ini belajar dilakukan dengan cara menerapkan rumusan pengetahuan yang telah dikuasai siswa dalam situasi yang berbeda/ situasi sebenarnya.

4. cooperating (bekerja sama) dalam hal ini belajar dilakukan dalam kelompok/ masyarakat belajar sehingga terjadi komunikasi dan bertukar pengetahuan.

5. transfering (memindahkan) dalam hal ini belajar dilakukan dengan cara memindahkan pengetahuan yang telah diperolehnya dalam konteks baru (Suprijono, 2009: 84)

Sejalan dengan strategi belajar model pembelajaran kontekstual di atas, model pembelajarankontekstual memiliki tujuh komponen utama, yaitu konstruktivisme (Constructivism), menemukan (Inquiry), bertanya (Questioning) masyarakat belajar (Learning Community), pemodelan (Modeling), refleksi (Reflection) dan penilaian yang sebenarnya (Authentic Assessment). Sebuah kelas dikatakan menggunakan model pembelajaran CTL jika menerapkan ketujuh komponen tersebut dalam pembelajarannya. Untuk melaksanakan hal itu tidak sulit. CTL dapat diterapkan dalam kurikulum apa saja, bidang studi apa saja, dan kelas yang bagaimanapun keadaannya.

Dalam pembelajaran kontekstual, program pembelajaran lebih merupakan rencana kegiatan kelas yang dirancang guru, yang berisi skenario tahap demi tahap tentang apa yang akan dilakukan bersama siswanya sehubungan dengan topik yang akan dipelajarinya. Dalam program tercermin tujuan pembelajaran, media untuk mencapai tujuan tersebut, materi pembelajaran, langkah-langkah pembelajaran, dan authentic assessmen-nya. Dalam konteks ini, program yang dirancang guru benar-benar rencana pribadi tentang apa yang akan dikerjakannya bersama siswanya (Nurhadi, $2003: 8$ ).

Secara umum tidak ada perbedaan mendasar format antara program pembelajaran konvensional dengan program pembelajaran kontekstual. Sekali lagi, yang membedakannya hanya pada penekanannya. Program pembelajaran konvensional lebih menekankan pada deskripsi tujuan yang akan dicapai (jelas dan operasional), sedangkan program untuk pembelajaran kontekstual lebih menekankan pada skenario pembelajarannya.

Atas dasar itu, saran pokok dalam penyusunan rencana pelaksanaan pembelajaran (RPP) berbasis kontekstual adalah sebagai berikut.

a. Nyatakan kegiatan pertama pembelajarannya, yaitu sebuah pernyataan kegiatan siswa yang merupakan gabungan antara standar kompetensi, kompetensi dasar, materi pokok dan pencapaian hasil belajar.

b. Nyatakan tujuan umum pembelajarannya

c. Rincilah media untuk mendukung kegiatan itu

d. Buatlah skenario tahap demi tahap kegiatan siswa 
e. Nyatakan authentic assessment-nya, yaitu dengan data apa siswa dapat diamati partisipasinya dalam pembelajaran. (Nurhadi 2003 : 15).

\section{PROSEDUR PENELITIAN}

Metode penelitian yang digunakan dalam penelitian ini adalah metode Penelitian Tindakan Kelas penelitian (PTK), yaitu penelitian yang dilakukan di dalam kelas yang bersifat reflektif dan siklis. Model PTK yang digunakan adalah model Elliot yang mensyaratkan bahwa kegiatan penelitian tindakan dilakukan melalui tahapan-tahapan penelitian yakni perencanaan umum, implementasi, monitoring implementasi dan efek, penjelasan kegagalan, dan rancangan ulang.

Penelitian ini dilakukan di sebuah sekolah dasar di Kabupaten Bandung dengansubjek penelitian sejumlah 16 orang siswa yang terdiri dari 9 siswi perempuan dan 7 siswa laki-laki.Untuk memperoleh data yang benar, digunakaninstrumen penelitian berupa catatan lapangan, pedoman wawancara, pengetesan, dokumentasi dan kuesioner. Teknik analisis data yang digunakan, yaitu analisis data kualitatif dengan persentase dan analisis data kuantitatif dilakukan untuk menentukan peningkatan hasil belajar anak dilihat dari setiap tindakan yang dilakukan oleh anak. Analisis ini dihitung dengan menggunakan rumus rata - rata.Terkait dengan data kualitatif, analisis data dilakukan dengan cara menata secara sistematis sesuai hasil pengamatan dan tindakan kelas sehingga diperoleh deskripsi data utuh dan runtut.

\section{HASIL PENELITIAN DAN PEMBEHASAN}

\section{Hasil Penelitian}

Pelaksanaan pembelajaran dalam penelitian ini dilakukan dalam dua siklus pembelajaran. Pada siklus pertama, pembelajaran dilaksanakan secara kooperatif dengan melibatkan siswa secara langsung untuk mengamati media yang disediakan guru.Berdasarkan hasil pengamatan pada saat kegiatan pembelajaran diketahui bahwa siswa terlihat antusias terhadap materi pembelajaran. Namun demikian, pada saat pengerjaan lembar kerja siswa masih tampak sejumlah kesulitan yang dihadapi siswa terutama dari kelompok yang dikategorikan kurang. Tetapi bagi kelompok yang berkategori pintar, mereka benar-benar mengerjakan lembar kerja siswa secara bersama-sama. Tetapi walaupun tidak nampak mengalami kesulitan, guru tetap memberikan kesempatan bertanya pada siswa pada kategori ini.

Sejalan dengan pelaksanaan pembelajaran pada siklus satu ini diperoleh data hasil belajar. Data hasil belajar siswa pada siklus satu dapat dilihat pada grafik sebagai berikut. 


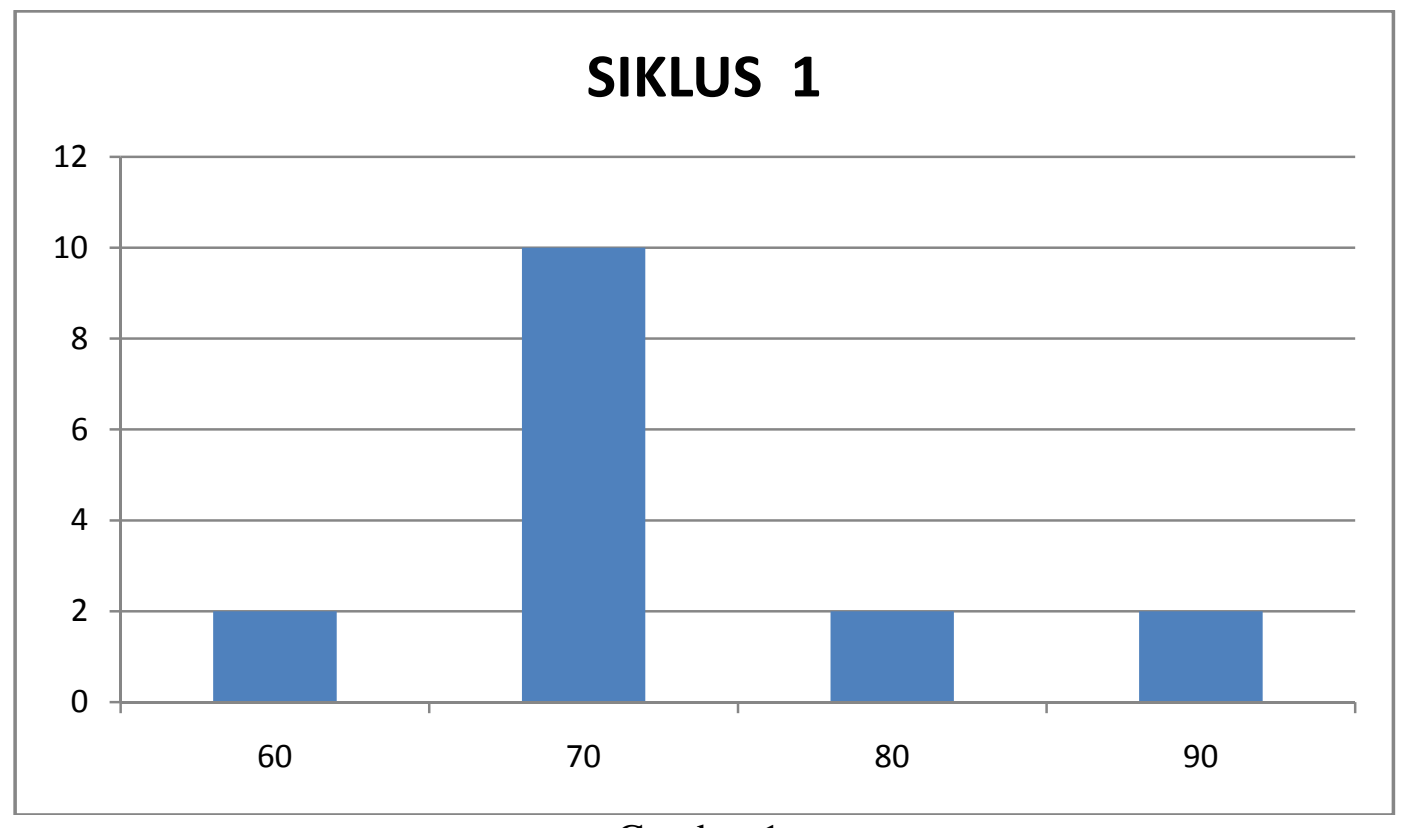

Gambar 1

Histogram Hasil Siklus Ke-1

Berdasarkan grafik di atas diperoleh nilai tertinggi siswa adalah 90, sedangkan nilai terendah adalah 60 dengan nilai rata-rata 72,50. Hal ini menunjukkan bahwa siswa telah mengalami peningkatan kemampuan jika dibandingkan dengan tahap awal sebelum perbaikan. Namun demikian, kemajuan yang diperoleh siswa belum optimal dan masih di bawah standar ketuntasan belajar minimal (SKBM) yaitu 75.

Pada siklus kedua, pembelajaran dilaksanakan langsung ke lapangan atau ke luar sekolah. Melalui kegiatan ke luar kelas ini siswa lebih antusias. Mereka lebih bisa bekerja sama dalam mengerjakan lembar kerja siswa. Pembelajaran pun menjadi semakin aktif dan menyenangkan bagi siswa. Sejalan dengan kondisi ini siswa tampak lebih mudah memahami materi. Pada saat diskusi kelas, sebagian besar siswa terlibat secara aktif. Di sisi lain guru pun lebih mampu mengaitkan materi pembelajaran dengan kehidupan nyata siswa sehingga materi pembelajaran lebih mudah sampaikan guru dan terkesan lebih kontekstual.

Sejalan dengan pelaksanaan pembelajaran pada siklus kedua ini diperoleh data hasil belajar. Data hasil belajar siswa pada siklus kedua dapat dilihat pada grafik sebagai berikut. 


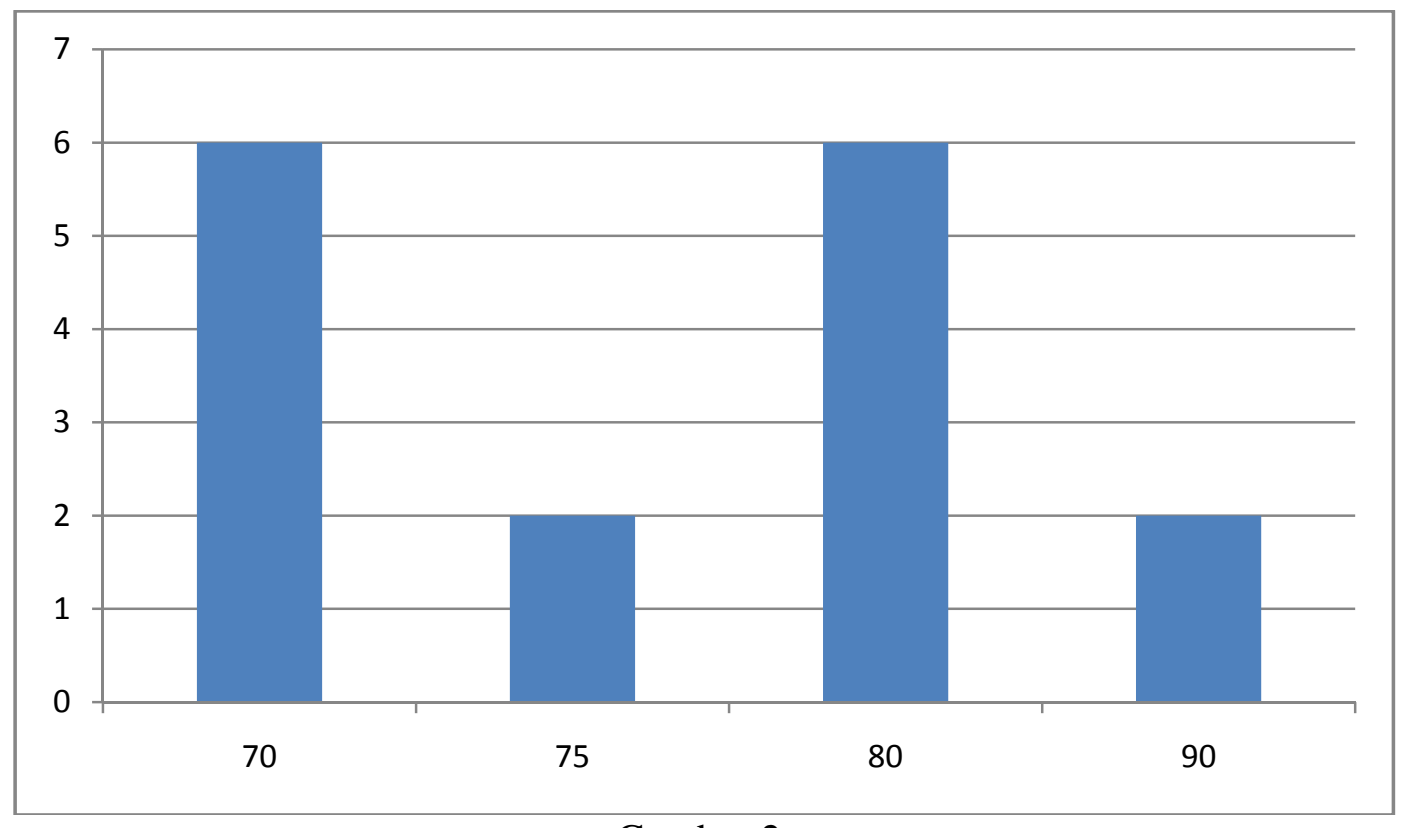

Gambar 2

Histogram Hasil Siklus Ke-2

Dari tabel dan grafik di atas diperoleh nilai tertinggi siswa adalah 90, sedangkan nilai terendah adalah 70 dengan nilai rata-rata 76,88. Hal ini menunjukkan bahwa siswa telah mengalami peningkatan kemampuan jika dibandingkan dengan hasil siklus pertama. Hasil di atas juga menunjukkan bahwa siswa telah menguasai materi perkembangan teknologi transportasi dengan model pembelajarankontekstual, dengan nilai memenuhi standar ketuntasan belajar minimal yaitu 75 .

Berdasarkan hasil pelaksanaan kedua siklus di atas, dapat penulis simpulkan bahwa model pembelajaran kontekstual dapat meningkatkan pemahaman siswa dalam perkembangan teknologi transportasi . Hal ini dapat dilihat dari perolehan rata-rata yang dicapai oleh siswa dalam setiap tindakan. Hasil gambaran perbaikan pembelajaran pada mata pelajaran IPS lengkapnya dapat dilihat dalam grafik di bawah ini. 


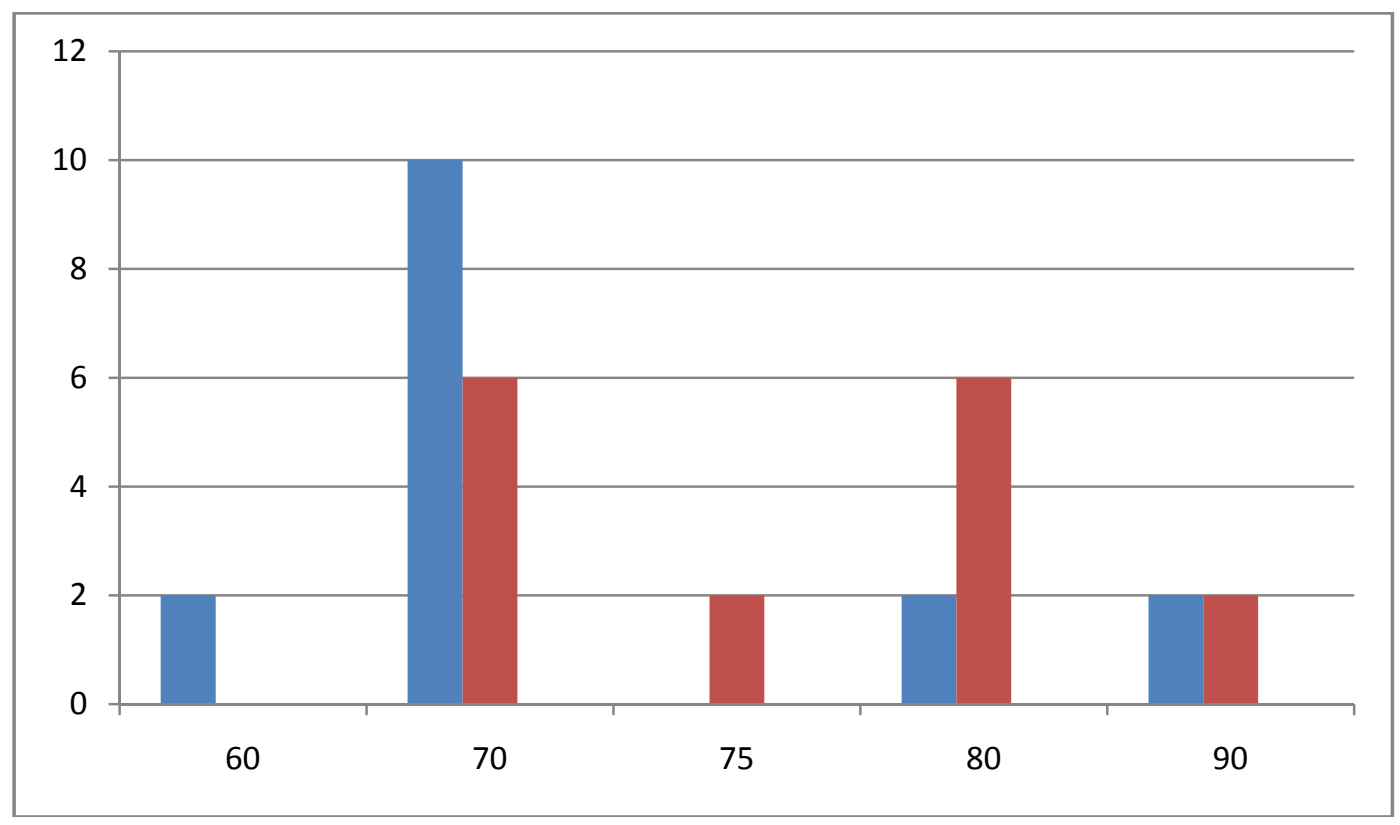

Gambar 3

Histogram Perbandingan Hasil Siklus Ke-1 dan 2

Grafik di atas menunjukkan pelaksanaan perbaikan pembelajaran IPS yang dilakukan telah berhasil.

\section{Pembahasan}

Proses pembelajaran IPS sebelum dilaksanakan perbaikan berlangsung kurang efektif, hal ini ditandai dengan munculnya beberapa masalah, antara lain (1) minimnya motivasi belajar siswa dalam pembelajaran, (2) indikasi penggunaan model penugasan/resitasi sehingga siswa tidak mendapat bimbingan dalam proses pembelajaran, dan (3) tidak ada interaksi aktif antara komponen belajar.Penerapan model pembelajaran kontekstual ternyata mampu mengatasi masalah tersebut sehingga dapat meningkatkan penguasaan siswa dalam perkembangan teknologi transportasi pada pembelajaran IPS di kelas IV. Hal ini ditandai dengan adanya peningkatan kemampuan siswa dalam perkembangan teknologi transportasi dengan model pembelajarankontekstual.

Hasil pembelajaran pada siklus I menunjukkan kenaikan dari data sebelum perbaikan. Hal ini berarti bahwa model pembelajarankontekstual dapat meningkatkan pemahaman siswa dalam perkembangan teknologi transportasi. Tetapi, pada siklus I masih ada siswa yang belum memenuhi standar ketuntasan belajar minimal (SKBM) dan nilai rata-ratanya masih rendah.Pada proses pembelajaran siklus II kegiatan siswa semakin aktif, hal ini terjadi karena motivasi belajar siswa tinggi sehingga materi perkembangan teknologi transportasi dapat dikuasai oleh siswa setelah guru menggunakan model pembelajaran kontekstual dalam menyampaikan materi pembelajarannya. Adanya peningkatan hasil belajar dalam siklus II dapat dilihat pada penguasaan siswa untuk materi pembelajaran perkembangan teknologi transportasi dengan model pembelajarankontekstual. 
Berdasarkan uraian di atas, dapat penulis simpulkan bahwa model pembelajaran kontekstual dapat meningkatkan pemahaman siswa dalam perkembangan teknologi transportasi . Hal ini dapat dilihat dari perolehan ratarata yang dicapai oleh siswa dalam setiap tindakan. Selain itu, berdasarkan hasil wawancara dengan guru, guru menyatakan pembelajaran dengan model kontekstual lebih memudahkan guru dalam meningkatkan pemahaman siswa. Para siswa pun menyatakan pembelajaran menjadi menyenangkan. Oleh sebab itu, model kontekstual sebaiknya digunakan dalam pembelajaran IPS di sekolah dasar.

\section{E. KESIMPULAN DAN SARAN}

1. Kesimpulan

a. Model pembelajaran kontekstual dapat diterapkan dalam pembelajaran IPS tentang perkembangan teknologi transportasi karena langkah-langkah model ini mampu dilaksanakan guru dengan efektif sehingga proses pembelajaran menjadi lebih kondusif dan siswa semakin aktif dan kreatif.

b. Model Pembelajaran kontekstual dapat digunakan untuk meningkatkan kemampuan siswa dalam memahami materi perkembangan teknologi transportasi. Hal ini ditunjukkan dengan meningkatnya pemahaman siswa dalam materi tersebut.

\section{Saran}

a. Guru diharapkan mampu memilih, menentukan, dan menggunakan model pembelajaran yang tepat dan sesuai dengan materi pelajaran yang disampaikannya. Salah satu model yang dapat diterapkan dalam pembelajaran IPS di SD tersebut adalah model pembelajaran kontekstual.

b. Kepala sekolah hendaknya mampu menjadi motivator guru untuk menerapkan berbagai model dan media pembelajaran sehingga guru secara terus-menerus melakukan pembaharuan dalam dunia pendidikan. Selain itu, kepala sekolah juga hendaknya menjadi fasilitator, sehingga pembaharuan yang dilakukan guru dalam pembelajaran dapat terealisasi dengan optimal.

\section{DAFTAR PUSTAKA}

Banks \& Ambrose, (1990). Teaching Strategies for the Social Studies. New York: Longman.

Barr, et.al. (1978) Defining The Social Studies. Virginia: NCSS

Ibrahim (2007) Proses Belajar MengajarCBSA. Bandung: Sinar Baru Algesindo

NCCS, (1994)."Curriculum Standar for Social Sudies, Expection for Excelence”. Washington: NCCS.

Nuhadi. (2002)Pendekatan Kontekstual. Jakarta: Depdiknas.

Soemantri, N.M. (2000). Menggagas Pembaharuan Pendidikan IPS. Bandung: Rosdakarya.

Sumaatmadja, N. (2001). Metode Pengajaran Ilmu Pengatahuan Sosial. Bandung: Alumni.

Suprijono, A. (2009) Cooperative Learning: Teori dan Aplikasi Pakem. Yogyakarta: Pustaka Pejalar.

Sutisyana(1997) Upaya Menumbuhkan Kemampuan Berpikir Kritis Siswa dalam Pembelajaran IPS. Tesis. Bandung: PPS UPI Bandung. (Tidak Diterbitkan) 
Winataputra, dkk. (2007). Materi dan Pembelajaran IPS di SD. Jakarta: Pusat Penerbitan Universitas Terbuka. 